It therefore becomes increasingly attractive to conclude that the two areas have been separated by continental drift either after, or probably during, the phase of volcanic activity.

Reference

Pulvertaft, T.C.R. and Clarke, D.B. (1966) New mapping on Svartenhuk Peninsula. Rapp. Grønlands geol. Unders., Nr. 11, $15-17$.

\title{
ANGIOSPERMOUS LEAVES FROM THE LOWER CRETACEOUS KOME FORMATION OF NORTHERN WEST GREENLAND
}

\section{K. Raunsgaard Pedersen}

The Kome Formation occurs on the north side of Nugssuaq peninsula $\left(70^{\circ} 5^{\prime} \mathrm{N}\right)$ in northern West Greenland. It extends from Ikorfat $\left(53^{\circ} 5^{\prime} \mathrm{W}\right)$ eastwards to Kâk.

The limnic sediments of the Kome Formation, comprising shales, coal seams and sandstones, lie on weathered Precambrian gneisses and are overlain by a younger limnic formation with more sandy sediments. The two formations are separated by a low-angle unconformity'at a height of $400-500 \mathrm{~m}$. The upper limnic formation has been shown by means of plant microfossils to belong to the lower part of the Upper Cretaceous. In the western part of the area the two limnic formations are overlain by marine sediments of Senonian age (Rosenkrantz, 1951).

Judging from micro- and macroscopic plant remains the Kome Formation is of Lower Cretaceous age (Barremian-Aptian). This is the age originally suggested by Heer (1883, p.157), but for a long time afterwards the age was thought to be Upper Cretaceous because 
representatives of younger floras were mixed up in the Kome flora and the Kome flora itself was misinterpreted.

Critial examination of the finds of angiosperms which had been reported earlier, together with the typical Lower Cretaceous ferns and gymnosperms, showed that there were no reliable finds of angiosperms from the Kome Formation (Koch, 1964).

The early reports of angiosperms in the Kome Formation having been discredited, and the age of the formation still being a matter for debate, there was obviously a need for new collections. Therefore in the early summer of 1967 the writer made an extensive collection of samples from the Kome Formation for spore and pollen analysis together with a collection of plant macrofossils from some of the best localities.

The most interesting find was made at Patorfik in the eastern part of the area, where a few specimens of angiospermous leaves were found in situ together with normal Kome plant fossils. This find indicates the existence, after all, of angiosperms in the Lower Cretaceous Kome Formation.

A full investigation of these finds and the microfossils is in progress.

\section{References}

Heer, O. (1883) Flora fossilis grönlandica. Zurich: J. Würster. Koch, B.E. (1964) Review of fossil floras and nonmarine deposits of West Greenland. Bull.geol. Soc. Amer., Vol. 75, 535-548.

Rosenkrantz, A. (1951) Oversigt over Kridt-og Tertiærformationens stratigrafiske forhold i Vestgr $\phi$ nland. Medd. dansk geol. Foren., Bd. 12, 155-158. 